\title{
Physico-chemical shelf-life indicators of meat from broilers given Moringa oleifera leaf meal
}

\author{
C. Wapi ${ }^{1}$, T.T. Nkukwana ${ }^{1}$, L.C. Hoffman ${ }^{2}$, K. Dzama ${ }^{2}$, E. Pieterse ${ }^{2}$, \\ T. Mabusela ${ }^{1} \&$ V. Muchenje ${ }^{1 \#}$ \\ ${ }^{1}$ Department of Livestock and Pasture Science, University of Fort Hare, P. Bag X 1314, Alice 5700, South Africa; \\ ${ }^{2}$ Department of Animal Sciences, Stellenbosch University, P. Bag X1, Matieland 7602, South Africa
}

(Received 3 October 2012; Accepted 26 February 2013; First published online 5 July 2013)

Copyright resides with the authors in terms of the Creative Commons Attribution 2.5 South African Licence. See: http://creativecommons.org/licenses/by/2.5/za/

Condition of use: The user may copy, distribute, transmit and adapt the work, but must recognise the authors and the South African Journal of Animal Science

\begin{abstract}
The objective of the study was to determine the effect of using Moringa oleifera leaf meal (MOLM) as an additive on physico-chemical shelf life indicators of meat from broilers. A total of 432 1-day-old chicks were randomly allocated to four treatments (TRT's). Water and feed was provided ad libitum. The feeding phases were pre-starter (0 to 7 days), starter (8 to 18 days), grower (19 to 28 days) and finisher (29 to 35 days).The four TRT's contained graded levels of the MOLM at $1000 \mathrm{~g} / \mathrm{ton}, 750 \mathrm{~g} / \mathrm{ton}, 500 \mathrm{~g} / \mathrm{ton}$ and $0 \mathrm{~g} / \mathrm{ton}$ (control), respectively. The birds were slaughtered at 35 days of age and the breast muscle was sampled for meat $\mathrm{pH}$, colour and drip loss measurements over 7 days. The $\mathrm{pH}$ levels in all the TRT's were constant from Day 1 to Day 5, peaking on Day 6, and then declining on Day 7. Using MOLM as an additive had a significant effect on chickens, with TRT1 having the highest lightness $\left(\mathrm{L}^{*}\right)$ values. The redness $\left(\mathrm{a}^{*}\right)$ values were the highest in TRT2. Using MOLM as an additive had an effect on yellowness $\left(b^{*}\right)$ values. Drip loss was not affected by the dietary treatments. Using MOLM as an additive in broiler feeds produced chicken breast with a light $\left(\mathrm{L}^{*}\right)$ appearance while shelf life indicators generally remained constant in the first 5-days of storage.
\end{abstract}

Keywords: Diet effect, drip loss, freshness, meat colour, meat $\mathrm{pH}$

"Corresponding author: vmuchenje@ufh.ac.za

\section{Introduction}

Chicken meat has several desirable nutritional characteristics such as high protein (Mothershaw et al., 2009), low lipid content and high polyunsaturated fatty acids. This makes it preferable, health wise, when compared to red meat. Broiler meat is, however, highly susceptible to lipid oxidation and bacterial contamination during storage. Lipid oxidation is reported to have adverse effects on meat quality parameters such as appearance (colour), aroma, juiciness, tenderness and flavour, thus leading to the reduction of the meat's shelf-life. Wood \& Enser (1997) recommended the use of dietary antioxidants to reduce lipid peroxidation in feed and the animal, and to preserve product quality. In recent years, the use of antibiotics as feed additives has been discouraged.

In response to this there has been an interest on the use of natural antioxidants from plants, and these antioxidants have gained popularity because they are believed to be safer than synthetic antioxidants (Moyo et al., 2011). One such plant of interest is Moringa oleifera which is reported to contain some significant levels of natural antioxidants, such as vitamin E, selenium (Khalafalla et al., 2010) and tannins, which are reported to decrease the rate of lipid and pigment oxidation. The aim of the current study was, therefore, to determine the effect of Moringa oleifera leaf meal (MOLM) as a feed additive on $\mathrm{pH}$, colour and drip loss changes of broiler chicken meat over time. The null hypothesis tested was that there is no effect on physico- 
chemical shelf-life indicators ( $\mathrm{pH}$, colour, drip loss) of broilers given Moringa oleifera leaf meal as an additive.

\section{Materials and Methods}

Four hundred and thirty two unsexed day old Aviane 48 broiler chicks were randomly allocated to four dietary treatments in 72 cages. Each cage housed six birds that were fed as a group. Water and feed were offered ad libitum. Dietary treatments (TRT's) were as follows: TRT1: $1000 \mathrm{~g} /$ ton MOLM; TRT2: 750 g/ton MOLM; TRT3: 500 g/ton MOLM; and TRT4: a negative control diet with no MOLM. Basal diets were formulated to meet all the bird's dietary nutrient requirements for the pre-starter (0 - 7 days), starter (8 - 18 days), grower (19 - 28 days), and finisher (29 - 35 days) phases. Body weight gain (BWG) and feed intake (FI) of chicks were recorded at the beginning of each week, starting from the weight at placement until weight before and after slaughter.

A day before slaughter all the chickens were weighed and not given feed overnight. After weighing, six birds/treatment were randomly selected and kept separately, 24 birds were therefore used for the experiment. Before slaughter they were electrically stunned (50 - 70 volts) for 5 seconds to render them unconscious and allowed to bleed. After plucking, the birds were eviscerated manually, and then carcasses were chilled at $4{ }^{\circ} \mathrm{C}$ overnight. On the following day the left breasts were deboned, skin removed and cut into halves longitudinally for the shelf-life trial. Each of the half left breasts were weighed and packed in Styrofoam trays which were over wrapped. Each tray was marked according to the treatment number and sample number, which then gave 12 trays per treatment. Thereafter the trays were stored at $4{ }^{\circ} \mathrm{C}$ in a cooler over seven days.

Three trays from each treatment were randomly removed from the cooler every day. Drip loss was determined by weighing the fillets, then readings were taken as weight before (WB) and blotted dry using a paper towel, then weighed again as weight after (WA). The drip loss percentage was then calculated as WB-WA/WB*100\%. After taking drip loss measurements, colour $\left(\mathrm{L}^{*}, \mathrm{a}^{*}, \mathrm{~b}^{*}\right)$ measurements were taken on the same fillets using Colour-guide $45 \%{ }^{\circ}$ colorimeter (BYK-Gardener GmbH, Geretsried, Germany), with a $20 \mathrm{~mm}$ diameter measurement area and illuminant D65-day light, $10^{\circ}$ standard observer. Three readings were taken by rotating the Colour Guide $90^{\circ}$ between each measurement, in order to obtain a representative average value of the colour. The machine was calibrated using the green standard before each measurement. The $\mathrm{pH}$ of the fillets was also determined, using the $\mathrm{pH}$ meter (CRISON pH 25, CRISON Instruments SA, Spain) calibrated before each measurement at $\mathrm{pH} 4$, pH 7 and $\mathrm{pH} 9$ standard solution. The above procedures were done once per day consecutively for seven days. The effect of using MOLM as feed additive on meat colour, $\mathrm{pH}$, and drip loss over time was analyzed using the analysis of variance (ANOVA) of GenStat (2008). Pairwise Comparisons of means were done using LSD (average) procedure in GenStat (2008). The statistical model used was: $Y_{\mathrm{ijk}}=\mu+\alpha_{\mathrm{i}}+\beta_{\mathrm{j}}+\mathrm{E}_{\mathrm{ijk}}$, where; $\mathrm{Y}_{\mathrm{ijk}}=$ variables ( $\left.\mathrm{L}^{*}, \mathrm{a}^{*}, \mathrm{~b}^{*}\right), \mathrm{pH}$ and drip loss; $\mu=$ constant; $\alpha_{\mathrm{i}}=$ effect of diet; $\beta_{\mathrm{j}}=$ effect of day; $\mathrm{E}_{\mathrm{ijk}}=$ random error.

\section{Results and Discussion}

There was no significant effect of TRT on feed intake and body weight gain of the chickens. This could be due to the fact that MOLM was added in small amounts so there was not much difference between the TRTS. Figure 1 shows the effect of TRT's over time (days) on the $\mathrm{pH}$ levels of chicken meat. Treatments, days and their interaction had an effect $(P<0.001)$ on $\mathrm{pH}$ with TRT2 having the highest value. On Day 7 the $\mathrm{pH}$ level on meat from chickens fed the TRT 2 diet was higher than that obtained on meat from broilers fed with TRT1, 3 and 4. This could be due to the high levels of vitamin C (ascorbic acid) in MOLM (Rweyemamu, 2006). Price \& Schweigert (1987) reported that meat with a pH greater than 5.8 may be more prone to spoilage and results in decreased shelf-life. The $\mathrm{pH}$ levels in all the treatments were generally constant from Day 1 to Day 5 and they peaked on Day 6 with a decrease on Day 7 except for TRT2. These observations are similar with the ones by Jang Ae Ra et al. (2011), who have shown that animals supplemented with diet containing antibiotics and the one containing vitamin $\mathrm{E}$ increased $\mathrm{pH}$ values when measured on day 1,3 , and 5 on chicken thighs compared to the meat from the chickens supplemented with a basal diet only during a five day storage. 


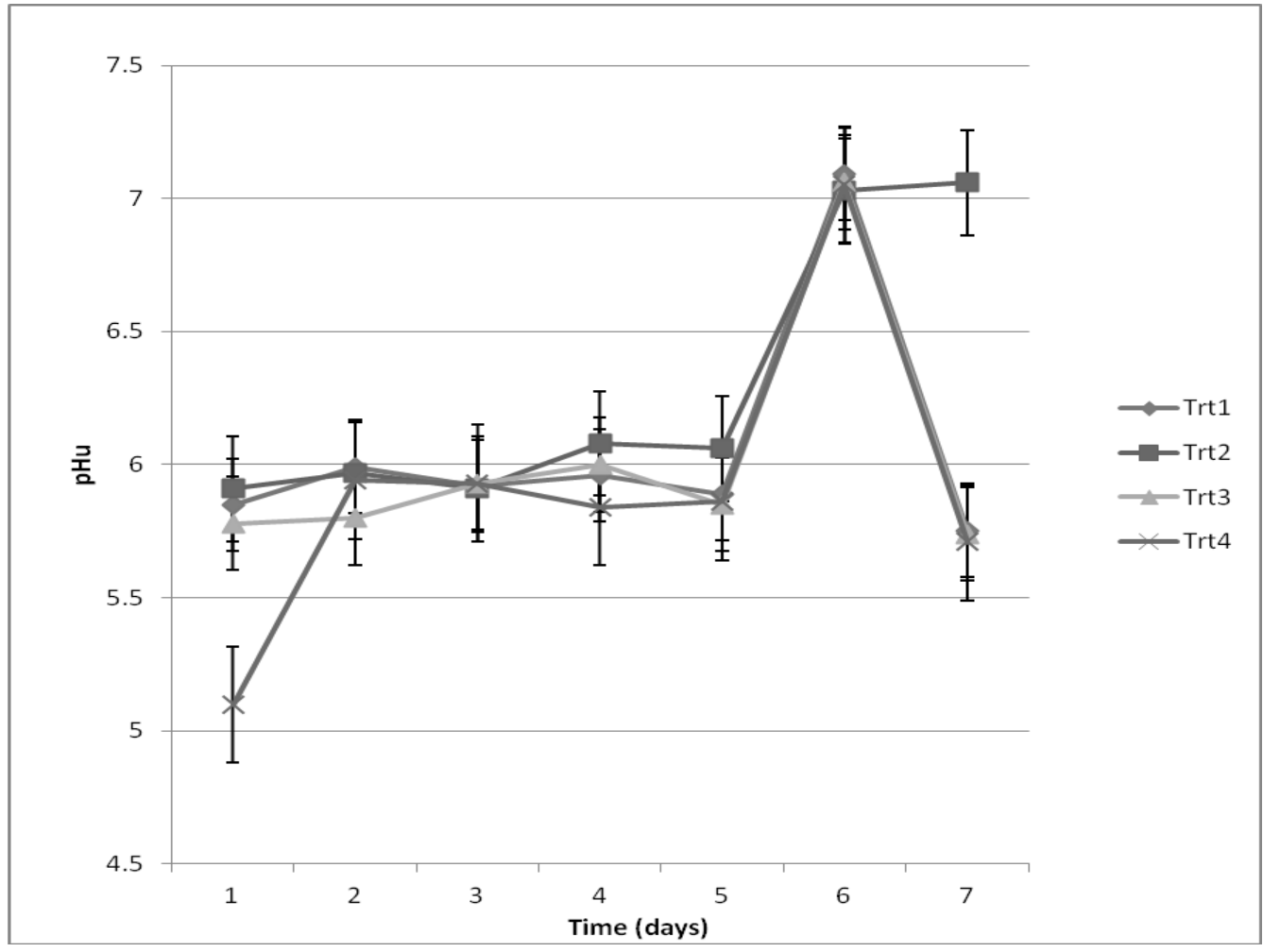

TRT1: 1000 g/ton Moringa oleifera leaf meal; TRT2: 750 g/ton Moringa oleifera leaf meal; TRT3: 500 g/ton Moringa oleifera leaf meal; and TRT4: a negative control diet with no Moringa oleifera leaf meal.

Figure 1 Effect of treatment over time (days) on the $\mathrm{pH}$ levels of chicken breast muscle.

During storage, days had an effect $(P<0.05)$ on the colour $\left(\mathrm{L}^{*}, \mathrm{a}^{*}, \mathrm{~b}^{*}\right)$ of the meat. The lightness $\left(\mathrm{L}^{*}\right)$ values were within the normal range of 50 - 56 from Days 1 - 5, but then decreased on Days 6 to 49.3 (Table 1). This relates to what has been reported by Petracci et al. (2004), that $\mathrm{L}^{*}$ of broiler meat is between 50 and 56. Lorenzo \& Gomez (2012) also observed an increase in $\mathrm{L}^{*}$ values during the first days of meat storage until a decrease was observed from Day 7. A study by Bingol \& Ergun (2011) have also shown that L ${ }^{*}$ values decreased at the end of meat storage. The drip loss values increased with storage time. According to Muchenje et al. (2009), accelerated pHu decline is related to unacceptable drip loss increase.

Table 1 Least square means and standard errors for shelf-life indicators of chicken meat during storage

\begin{tabular}{lrrrrrrrr}
\hline \multirow{2}{*}{ Attributes } & \multicolumn{7}{c}{ Days } \\
\cline { 2 - 7 } & \multicolumn{1}{c}{1} & \multicolumn{1}{c}{3} & \multicolumn{1}{c}{4} & \multicolumn{1}{c}{5} & 6 & 7 & \\
\hline $\mathrm{L}^{*}$ & $54.9^{\mathrm{de}}$ & $54.0^{\mathrm{d}}$ & $52.7^{\mathrm{c}}$ & $54.2^{\mathrm{d}}$ & $55.6^{\mathrm{e}}$ & $49.3^{\mathrm{b}}$ & $47.3^{\mathrm{a}}$ & 1.28 \\
$\mathrm{a}^{*}$ & $4.8^{\mathrm{d}}$ & $3.2^{\mathrm{a}}$ & $4.9^{\mathrm{d}}$ & $5.3^{\mathrm{e}}$ & $3.5^{\mathrm{b}}$ & $4.5^{\mathrm{c}}$ & $4.8^{\mathrm{d}}$ & 0.53 \\
$\mathrm{~b}^{*}$ & $12.9^{\mathrm{c}}$ & $11.6^{\mathrm{a}}$ & $13.2^{\mathrm{d}}$ & $12.3^{\mathrm{b}}$ & $12.8^{\mathrm{c}}$ & $15.2^{\mathrm{f}}$ & $14.1^{\mathrm{e}}$ & 0.62 \\
Drip loss & $1.1^{\mathrm{a}}$ & $1.5^{\mathrm{b}}$ & $2.3^{\mathrm{c}}$ & $2.4^{\mathrm{c}}$ & $2.8^{\mathrm{e}}$ & $2.7^{\mathrm{d}}$ & $2.8^{\mathrm{e}}$ & 0.18 \\
\hline
\end{tabular}

$\overline{\mathrm{abc}}$ means with different superscripts in the same row are different $(P<0.05)$.

As shown in Table 2 the TRT's had a significant effect $(P<0.05)$ on colour of broiler meat, which could be attributed to the antioxidant activity of MOLM (Moyo et al., 2012). Bucklley \& Morrissey (1992) reported that feeding poultry higher level of natural dietary antioxidants provides the poultry industry with a 
simple method for improving oxidative stability and shelf-life of poultry meats. The highest lightness ( $\left.\mathrm{L}^{*}\right)$ values were observed in meat from TRT1, with TRT4 having lowest $\mathrm{L}^{*}$ values. The highest $\mathrm{b}^{*}$ values were observed in meat from TRT1 broilers. This could be due to beta carotene content consumed by chickens in this treatment (Richter et al., 2003; Reyes-Sanchez et al., 2006; Moyo et al., 2011). Dietary treatments had no $(P>0.05)$ significant effect on drip loss. This concurs with the findings by Lawrie (1998) that diet does not seem to affect the drip loss and Comale et al. (2011) reported that drip and cooking losses are not globally influenced by the use of the phytotherapic compound in the diets.

Table 2 Least square means and standard errors for $\mathrm{L}^{*}, \mathrm{a}^{*}, \mathrm{~b}^{*}$ and drip loss of meat samples (chicken) as affected by treatment

\begin{tabular}{lcrrrr}
\hline & \multicolumn{3}{c}{ Treatments } & \multirow{2}{*}{ SEM } \\
\cline { 2 - 4 } Attributes & TR1 & TRT2 & TRT3 & TRT4 & \\
\hline L $^{*}$ & $55.4^{\mathrm{b}}$ & $51.8^{\mathrm{a}}$ & $51.7^{\mathrm{a}}$ & $51.4^{\mathrm{a}}$ & 0.97 \\
$\mathrm{a}^{*}$ & $4.1^{\mathrm{b}}$ & $3.7^{\mathrm{a}}$ & $5.2^{\mathrm{d}}$ & $4.8^{\mathrm{c}}$ & 0.40 \\
$\mathrm{~b}^{*}$ & $14.1^{\mathrm{d}}$ & $12.4^{\mathrm{a}}$ & $13.3^{\mathrm{c}}$ & $12.9^{\mathrm{b}}$ & 0.47 \\
Drip loss & 2.1 & 2.4 & 2.3 & 2.0 & 0.13 \\
\hline
\end{tabular}

\footnotetext{
${ }^{\mathrm{abc}}$ means with different superscripts in a row are different $(P<0.05)$,

TRT1:1000 g/ton Moringa oleifera leaf meal;

TRT2: 750 g/ton Moringa oleifera leaf meal;

TRT3: 500 g/ton Moringa oleifera leaf meal;

TRT4: a negative control diet with no Moringa oleifera leaf meal.
}

\section{Conclusion}

Using MOLM as an additive affected the colour and $\mathrm{pH}$ of broiler meat as well as the stability of these parameters during storage. The colour (lightness) and $\mathrm{pH}$ of the meat were stable during storage until Day 6 when it started decreasing, while drip loss increased with storage time.

\section{Acknowledgements}

The authors wish to thank the Thuthuka Programme which is under National Research Foundation (NRF) of South Africa for the financial support of this project (T154). The trial and laboratory analyses were done at Stellenbosch University.

\section{References}

Bingol, E.B. \& Ergun, O., 2011. Effects of modified atmosphere packaging (MAP) on the micro-biological quality and shelf-life of ostrich meat. Meat Sci. 88, 774-785.

Buckley, D.J. \& Morrissey, P.A., 1992. Animal production highlights. In: Vitamin E and Meat Quality. Hoffmann-La Roche Ltd. Basel, Switzerland. pp. 24-27.

Comale, P., Parantola, M., Lussiana, C., Tassone, S., Castellina, C. \& Battaglini, L.M., 2011. Effects of ginger (Zingiber officinale) and European Stoneseed (Lithospermum officinale) extracts on performances, meat quality and fatty acid composition of finishing bulls. Ann. Warsaw Univ. of Life Sci. - SGGW. Anim. Sci. 49, 11-20.

Jang, A.R., Ham, J.S., Kim, D.N., Seol, K.H., Oh, M.H., Chae, H.S., Kim, S.H. \& Kim, D.H., 2011. Dietary supplementation of resveratrol and methoxylated resveratrol effects on chicken thigh meat quality. Korean J. Poult. Sci. 38, 315-322.

Khalafalla, M.M., Abdellatef, E., Dafalla, H.M., Nassrallah, A.A., Aboul-Enein, K.M., Lightfoot, D.A., EI-Deeb, F.E. \& EI-Shemy, H.A., 2010. Active principle from Moringa oleifera Lam leaves effective against two leukemias and a hepatocarcinoma. Afr. J. Biotechnol. 49, 8467-8471.

Lawrie, R.A., 1998. Lawrie’s Meat Science. Woodhead Publ. Ltd. 6, 336. 
Lorenzo, J.M. \& Gomez, M., 2012. Shelf-life of fresh foal meat under MAP, overwrap and vacuum packaging conditions. Meat Sci. 92, 610-618.

Mothershaw, A.S., Gaffer, T., Kadim, I., Guizani, N., Al-Amri, I., Mahgoub, O. \& Al-Bahry, S., 2009. Quality characteristics of broiler chicken meat on salt at different temperatures. Int. J. Food Propt. 12, 681-690.

Moyo, B., Masika, P.J., Hugo, A. \& Muchenje, V., 2011. Nutritional characterization of Moringa oleifera Lam leaves. Afr. J. Biotech. 10, 12925-12933.

Moyo, B., Oyedemi, S., Masika, P.J. \& Muchenje, V., 2012. Polyphenolic content and antioxidant properties of Moringa oleifera leaf extracts and enzymatic activity of liver from goats supplemented with Moringa oleifera leaves/sunflower seed cake. Meat Sci. 91, 441-447.

Muchenje, V., Dzama, K., Chimonyo, M., Strydom, P.E., Hugo, A. \& Raats, J.G., 2009. Some biological aspects pertaining to beef eating quality and consumer health: A review. Food Chem. 112, 279-289.

Petracci, M., Betti, M., Bianchi, M. \& Cavani, C., 2004. Colour variation and characterization of broiler breast meat during processing in Italy. Poult. Sci. 83, 2086-2092.

Price, J.F. \& Schweigert, B.S., 1987. The science of meat and meat products. Food \& Nutr. Press, Trumbull, Conn. 3.

Reyes-Sanchez, N., Sporndly, E. \& Ledin, I., 2006. Effect of feeding different levels of foliage from Moringa oleifera to creole dairy cows on intake, digestibility, milk production and composition. Livest. Sci. 101, 24-31.

Richter, N., Siddhuraju, P. \& Becker, K., 2003. Evaluation of nutritional quality of Moringa (Moringa oleifera Lam) leaves an alternative source for Nile tilapia (Orechromis niloticus1.) Aquaculture 217, 599-611.

Rweyemamu, L.M.P., 2006. Challenges in the development of micronutrient-rich food ingredients from soya beans and Moringa oleifera leaves: Moringa and other highly nutritious plant resources: Strategies, standards and markets for a better impact on nutrition in Africa, Accra, Ghana, November 16-18, 2006.

Wood, J.D. \& Enser, M., 1997. Factors influencing fatty acids in meat and the role of antioxidants in improving meat quality. Br. J. Nutr. 78, S49-S60. 